\title{
Urban stormwater - greywater management system for sustainable urban water management at sub-watershed level
}

\author{
Amarpreet Singh Arora ${ }^{1, *}$ \\ ${ }^{1}$ Marwadi University, Faculty of Engineering, Department of Environmental Science and \\ Engineering, Rajkot-360003, Gujarat, India
}

\begin{abstract}
Urban water management involves urban water supply (import, treatment and distribution of water), urban wastewater management (collection, treatment and disposal of urban sewage) and urban storm water management. Declining groundwater tables, polluted and declining sources of water, water scarcity in urban areas, unsatisfactory urban water supply and sanitation situation, pollution of receiving water bodies (including the ground water), and urban floods have become the concerns and issues of sustainable urban water management. This paper proposes a model for urban stormwater and sewage management which addresses these concerns and issues of sustainable urban water management. This model proposes segregation of the sewage into black water and greywater, and urban subwatershed level stormwater-greywater management systems. During dry weather this system will be handling only the greywater and making the latter available as reclaimed water for reuse in place of the fresh water supply. During wet weather, the system will be taking care of (collection and treatment) both the storm water and the greywater, and the excess of the treated water will be disposed off through groundwater recharging. Application of this model in the Patiala city, Punjab, INDIA for selected urban sub-watersheds has been tried. Information and background data required for the conceptualization and design of the sub-watershed level urban stormwater-greywater management system was collected and the system has been designed for one of the sub-watersheds in the Patiala city. In this paper, the model for sustainable urban water management and the design of the Sub-watershed level Urban Stormwater-Greywater Management System are described.
\end{abstract}

\section{Introduction}

Urbanization directly impacts water quantity and quality owing to construction of urban infrastructure and changes in landscape and runoff conveyance networks $[1,2]$. The increased percentage of impervious surfaces lead to increased runoff volumes, whilst a variety of anthropogenic activities produce a range of pollutants such as nutrients, solids and organic matter, which accumulate on catchment surfaces [3-8]. As a result, both hydrologic and water quality characteristics are significantly affected [9-12]. The

\footnotetext{
*Corresponding author: amarpreetsingh.arora@marwadieducation.edu.in
} 
stormwater management should in fact be an integral part of sustainable urban water management with focus on localized or decentralized collection, treatment and disposal of the stormwater may be through, reuse and groundwater recharging. But this should be done without causing urban floods and pollution of urban groundwater resources. To address these concerns, a research study was conducted at a model city Patiala $\left(29^{\circ} 49^{\prime}\right.$ and $30^{\circ} 47^{\prime}$ north latitude, $75^{\circ} 58^{\prime}$ and $76^{\circ} 54^{\prime}$ east longitude), an erstwhile princely city of the Punjab state of India.

This paper proposes an integrated model for the recycling of both wastewater (predominantly greywater) and urban stormwater as both stormwater and greywater are usually of better quality than untreated sewage or industrial discharge [13] and as such has better public acceptance for utilisation. An experimental treatment system was developed for one of the sub-watershed of the Patiala city. This system during its first phase was run on stormwater only and then greywater was introduced into the system during non-rainy period. The outcomes of this research can aid the urban water managers in better water management of the urban areas.

\section{Material and methods}

\subsection{Selection of the urban catchments}

Five urban sub-watersheds were identified within Patiala to serve as catchments for the study. The location of the study areas is shown in Figure 1.

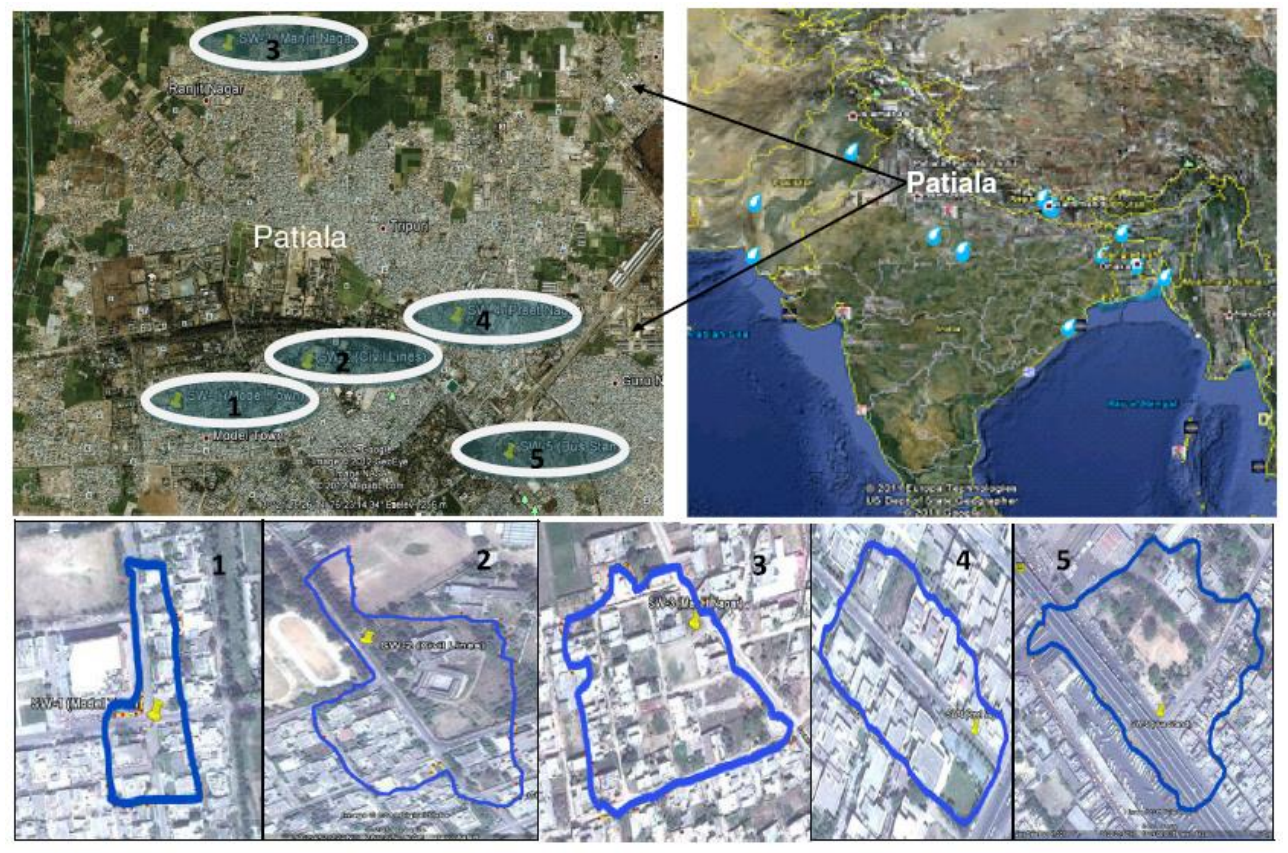

Model Town

Civil Lines

Manjit Nagar

Preet Nagar

Bus Stand

Fig. 1. Map showing the locations of the sub-watersheds studied.

The five catchments encompass a wide spectrum of land uses, housing densities and other land development characteristics. Civil Lines area is a predominantly residential catchment. Manjit Nagar, located near Seona village, is a mix of rural and residential acreage. Preet Nagar contains mixed urban development. Model Town is a predominately 
commercial area near Tagore theatre. Lastly, Bus Stand area is a heavily travelled and polluted catchment. The study catchments were chosen within a five kilometer radius as to have uniformity in the geological, topographical and climatic variables. Despite differing land use forms, all five catchments were prone to flooding even during modest of rainfall. Information on the land uses was obtained through the Department of Town and Country Planning Punjab, Patiala Municipal Corporation, local zoning maps and physical survey visits.

\subsection{Development of sustainable urban water management model for the city}

Sustainable and environmentally sound management of urban water should incorporate the following:

- Avoiding stormwater flooding in urban areas

- Maximizing the local groundwater recharging by the storm water

- Avoiding the groundwater contamination from the polluted stormwater and greywater

- Minimizing and/or eliminating stormwater runoff beyond the urban limits

- Re-using the greywater as reclaimed water

The urban area can in fact be divided into a multitude of sub-watersheds and decentralized urban water management systems at the urban sub-watershed levels may be used. The management system will include the following three components:

- Sub-watershed level combined stormwater and greywater collection system

- Water treatment system

- Groundwater recharge system

Development of an integrated urban water management system comprising of these three components and serving the above mentioned objectives has been attempted for the Patiala city, Punjab, India. Five sub-watersheds, all suffering from storm water flooding even with small rainfall events (as low as $4 \mathrm{~mm}$ rainfall), were chosen from within the city for the development of water management systems.

The accumulated storm water of each of the five sub-watersheds during 12 rainfall events was sampled and characterized for knowing and assessing the pollution levels of the stormwater. Hydrological methods have been used for estimating the stormwater generation rates of the sub-watersheds. The assessed/estimated stormwater characteristics and quantities have been used to conceptualize and design the storm water treatment and disposal system. An experimental water treatment system has been developed and studied for its performance in removing the pollutants from the stormwater.

The management system conceptualized would consistently satisfy the treated effluent quality requirements for disposal through the groundwater recharging. Operation and control of the conceptualized system will not require any human intervention especially during the rainfall events. Human intervention has been limited to the annual prescheduled maintenance (may be prior to the monsoon).

Storm water characterization studies have indicated removal of suspended solids and treatment for the BOD/COD strength reduction as the essential features of the conceptualized treatment system. Viability of the treatment through the highly varying and random intervening dry period (ADD) was identified as the essential feature [14].

For ensuring this, collection, conveyance and treatment of even the greywater along with the storm water of the sub-watershed has been envisioned. Such a strategy is believed to make available of the treated greywater as reclaimed water for reuse within the subwatershed. 


\section{Results and discussion}

\subsection{Pilot scale experimental treatment system}

The experimental treatment plant was designed and fabricated. Line diagram of the experimental treatment plant is shown in Figure 2.

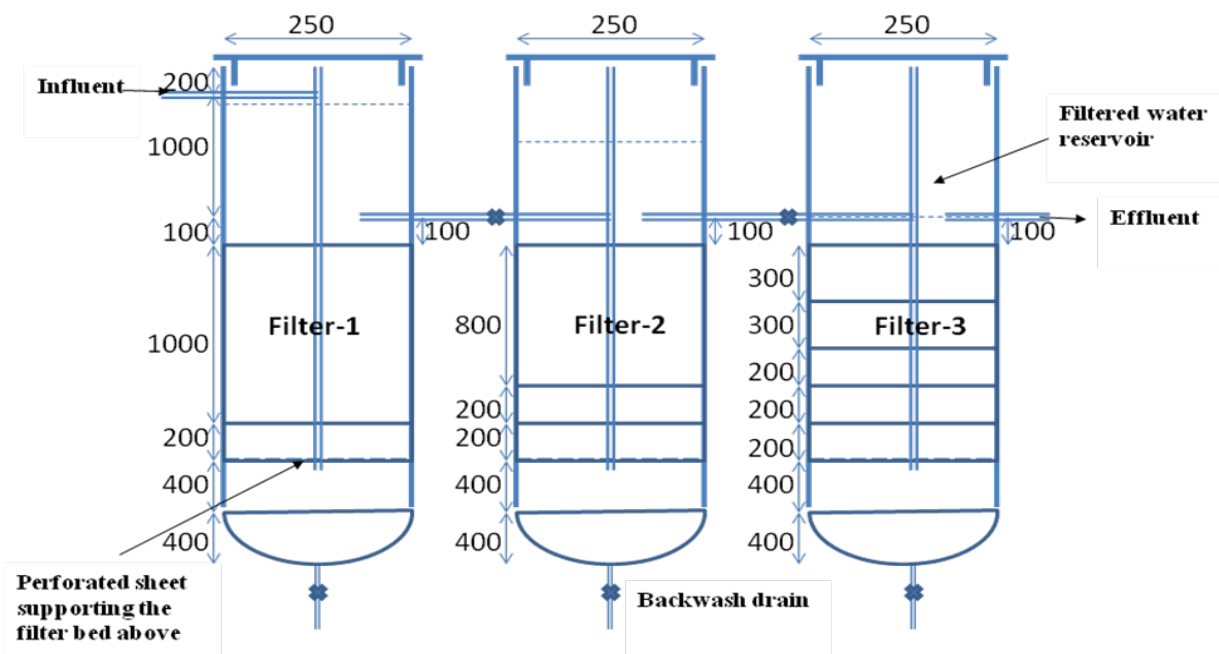

Fig. 2. Three-stage Multi-grade up-flow roughing Filter.

Stormwater treatment unit was installed near the western gate of the Thapar University, Patiala for evaluating its performance in terms of removal efficiency. This site was chosen because being a low lying area with inadequate stormwater conveyer facilities the area outside the gate was prone to flooding during rains. Stormwater samples were collected from the inlet and outlet of the unit and were analyzed for $\mathrm{BOD}_{5}$ at $20^{\circ} \mathrm{C}, \mathrm{COD}, \mathrm{TSS}, \mathrm{TDS}$, Turbidity, Total and Fecal Coliform count. Results obtained have been listed in the Table 1.

Table 1. Results of the removal efficiency of Three-stage Multi-grade up-flow roughing Filter.

\begin{tabular}{|c|c|c|c|c|}
\hline Parameter & Method/Reference & Inlet & Outlet & $\begin{array}{l}\text { Removal } \\
\text { efficiency }\end{array}$ \\
\hline BOD $(\mathrm{mg} / \mathrm{L})$ & $\begin{array}{l}\text { APHA (2005) "Manual standard } \\
\text { method" 21st edition (5210: B) }\end{array}$ & $9.2-22.5$ & $0.7-1.2$ & $92-95 \%$ \\
\hline $\mathrm{COD}(\mathrm{mg} / \mathrm{L})$ & $\begin{array}{l}\text { Closed Reflux Method, APHA } \\
\text { (2005): (5220: B) }\end{array}$ & $112-240$ & $28-46$ & $69-81 \%$ \\
\hline TSS (mg/L) & $\begin{array}{l}\text { Total suspended solids dried at } \\
103-105^{\circ} \mathrm{C}, \text { APHA (2005): }(2540 \text { : } \\
\text { D) }\end{array}$ & $345-434$ & $23-30$ & $89-94 \%$ \\
\hline TDS (mg/L) & $\begin{array}{l}\text { Total dissolved dried at } 180^{\circ} \mathrm{C} \text {. } \\
\text { APHA (2005): }(2540: \mathrm{C})\end{array}$ & $215-332$ & $196-240$ & $30-37 \%$ \\
\hline $\begin{array}{l}\text { Turbidity } \\
\text { (NTU) }\end{array}$ & Nephelometric Method & $1180-1572$ & $18.6-40$ & $96-98.8 \%$ \\
\hline $\begin{array}{l}\text { Total Coliform } \\
\text { (MPN/100 mL) }\end{array}$ & $\begin{array}{l}\text { Serial dilution method, APHA } \\
\text { (2005): }(9221: \mathrm{B}, \mathrm{C})\end{array}$ & $430000-730000$ & $940-2400$ & $99.4-99.8 \%$ \\
\hline $\begin{array}{l}\text { Fecal Coliform } \\
\text { (MPN/100 mL) }\end{array}$ & $\begin{array}{l}\text { Serial dilution method, APHA } \\
\text { (2005): }(9221: \mathrm{B}, \mathrm{C})\end{array}$ & $230000-310000$ & $70-750$ & $99.6-99.9 \%$ \\
\hline
\end{tabular}


The treatment plant was first run with tap water so that the dissolved and suspended impurities of the filter media were washed out. The treatment unit was run on-site on storm water sample immediately after the rainfall event. The plant was run during three rainfall events. Each time after running at constant flow rate for the duration, much longer than the HRT of the treatment plant, water samples were collected from both the inlet and the outlet. The collected samples were then analysed for BOD, COD, TSS, TDS, Turbidity and Coliform count for evaluating the performance (removal efficiency) of the treatment plant.

\subsection{Conceptualized system for sub-watershed level stormwater-greywater management}

The urban stormwater management system conceptualized is supposed to perform three core functions: stormwater collection, treatment and disposal of the treated stormwater through reuse as reclaimed water and through ground water recharging. The system in addition to the stormwater will also be handling the greywater of the sub-watershed.

The stormwater treatment system conceptualized for the urban sub-watersheds is schematically shown in Figure 3. The circular design has been formulated taking into account the less availability of land in developing countries.

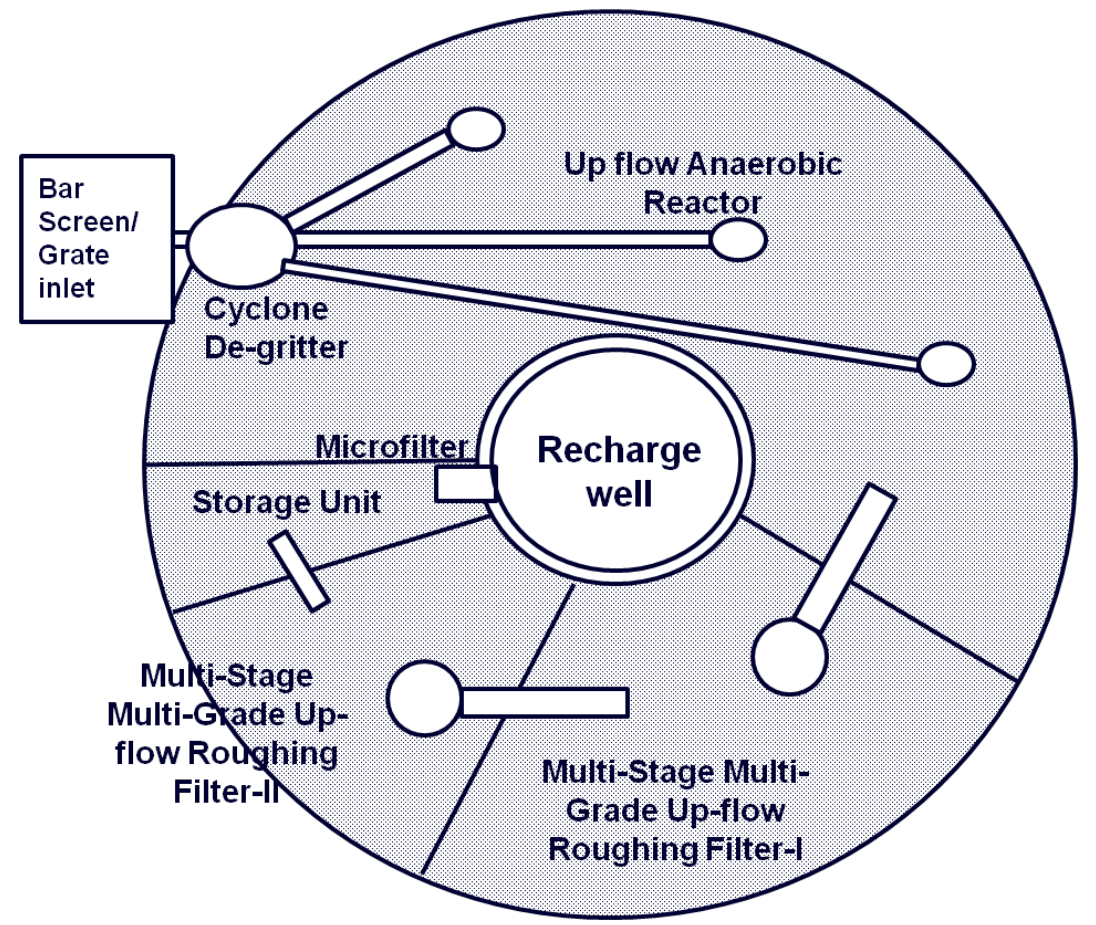

Fig. 3. Sub-watershed level stormwater-greywater management system.

Stormwater generated in the sub-watershed will flow as sheet flow for the first few meters distance then as shallow concentrated flow and enter the storm sewer inlet. If gutters are provided then the stormwater flow will be through gutters prior to entry into the storm sewer inlets. The storm sewer inlets are connected to the storm sewer through catch basins. The sewer inlet with bar screen or grating will remove larger particles like leaves, rags, etc from the stormwater. Catch basins will help in the removal of grit and floating material from the stormwater. Greywater will also be allowed to enter the storm sewers, designed to 
carry the greywater during dry weather at above the self cleansing velocity and stormwater during wet weather at below the storm sewer scour velocity.

Under normal conditions (dry weather conditions) treated stormwater will be held in the storage and will be pumped and supplied as reclaimed water to the nearby areas for reuse and no treated effluent will flow into the recharge well.

Under wet weather conditions the treated stormwater will be overflowing the storage provided and will get into the recharge well through a micro-filter or slow sand filter. Stormwater diversion would be provided for the case when combined stormwater and greywater flow is beyond the capacity of the system.

Different units of the treatment system can be sized to handle the expected stormwater at 90 percentile rainfall event. Provisions may be made at the grate inlet for diverting and transporting out excess stormwater flows. Filtered water storage facility can be sized to store the maximum greywater flows expected. Hydraulic design of the treatment system may be such that all units will remain submerged in water and no pumping is required for the stormwater and/or greywater to flow through the treatment system.

The treated water collected into the storage facility can be pumped and reused as reclaimed water. Treated water overflowing the storage facility can be disposed off through ground water recharging. The overflowing water may be finally filtered through a microfilter or slow sand filter and then allowed into a recharge well for ground water recharging. All the units of the stormwater treatment system may be arranged peripheral to the recharge well. The micro-filter/slow sand filter may be provided over the recharge well. Hydraulic design of the system can be such that the treatment system will remain submerged in water throughout.

\section{Conclusions}

Recycling of stormwater as well as greywater is an important strategy for improving urban water cycle management, given the current and increasing stresses on water resources throughout urban centres of India, and much of the world. In rapidly growing cities, the absence of infrastructure creates a demand for small-scale wastewater treatment and improved sanitation facilities. Decentralised water management has a potential for alleviating the water-related problems. Since there is insufficient water available, wastewater and stormwater should be recognised as a significant, growing and reliable water resource. The reclaimed water can fulfil the demand for toilet flushing and could certainly contribute to relieving the pressure on the ground water sources. Also the system can help in avoiding floods during the rainy season. Integrating greywater recycling could prove to be a very useful strategy not only in keeping treatment unit in live condition but also providing a fixed amount of water volume as it is independent of seasonal variations. Lastly if sustainable water management is to be achieved, the three urban water streams potable supply, wastewater and stormwater - should be integrated into the management of the total urban water cycle.

\section{Acknowledgement}

Author would like to extend thanks to Marwadi University, Rajkot for providing the platform to share my research on an International platform and School of Energy and Environment of Thapar University, Patiala for providing the infrastructural and laboratory facilities for under taking this research work. 


\section{References}

1. A. Goonetilleke, E. Thomas, S. Ginn, Understanding the role of land use in urban stormwater quality management, J. Environ. Mgmt. 74, 31-42 (2005)

2. J. Marsalek, W.E. Watt, B.C. Anderson, Water Sc. Tech. 53, 175-183 (2006)

3. US EPA, Results of the Nationwide Urban Runoff Program, Vol. 1-Final Report, NTIS access number PB84-18552, (Washington, DC, 1983)

4. H. Ha, M.K. Stenstrom, Water Research 37, 4222-4230 (2003)

5. B.E. Hatt, A. Deltic, T.D. Fletcher, J. Environ. Mgmt. 79, 102-113 (2006)

6. P. Mahbub, A. Goonetilleke, G.A. Ayoko, P. Egodawatta, T. Yigitcanlar, Water Sc. Tech. 63, 2077-2085 (2011)

7. G.F. Birch, C. Matthai, M.S. Fazeli, Urban Water J. 3, 69-77 (2006)

8. M.F. Chow, Z. Yusop, S.M. Shirazi, Environ. M. Assess. 185, 8321-8331 (2013)

9. G.P. Codner, E.M. Laurenson, R.G. Mein, Hydrologic effects of urbanization: a case study, Proceedings of the Hydrology and Water Resources Symposium, IE, Australia, 201-205 (1988)

10. ASCE, J. Hyd. Div. ASCE 101, 449-468 (1975)

11. R.G. Mein, A.G. Goyen, Urban Runoff, Civil Engg. Trans. IE, Australia CE30, 225-238 (1988).

12. J.J. Sansalone, J.P. Hird, F.K. Cartledge, M.E. Tittlebaum, Water Environ. Research 77, 348-65 (2005)

13. V.G. Mitchell, R.G. Mein, T.A. McMahon, Aust. J. of Water Resources 6, 31-43 (2002)

14. A.S. Arora, A.S. Reddy, Bul. of Environ. Cont. and Tox. 92, 36-43 (2014) 